КИРИЗЛІЕВ О.Ф.

\title{
ОСОБЛИВОСТІ РЕАЛІЗАЦІЇ ТРУДОВИХ ПРАВ ПРАЦІВНИКАМИ ФІНАНСОВИХ УСТАНОВ
}

У статті наголошено, що держава створює умови для повного здійснення громадянами права на працю, гарантує рівні можливості у виборі професії та роду діяльності, реалізує програми професійного навчання, підготовки та перепідготовки кадрів відповідно до суспільних потреб, але в той самий час не встановлено всієї цілісної системи реалізації гарантій і захисту цих прав. Визначено, що трудові права працівників фінансових установ варто розглядати в аспекті двох груп прав: основних прав працівників фінансових установ, тобто тих прав, які $\epsilon$ базовими для будь-яких сфер, у яких використовується наймана праця та які, безумовно, $\epsilon$ характерними і для установ, винятковим видом діяльності яких $є$ надання фінансових послуг; спеціальних прав працівників фінансових установ, тобто прав, характерних винятково для працівників фінансових установ та які встановлені у спеціальних нормативно-правових актах, які функціонують у цій сфері. 3'ясовано, що деякі категорії службовців фінансових установ, такі як працівник, відповідальний за проведення фінансового моніторингу, керівники та головні бухгалтери фінансових установ, окрім іншого, повинні володіти бездоганною діловою репутацією та відповідати іншим кваліфікаційним вимогам, встановленим законодавством. Ділова репутація таких працівників повинна відповідати, зокрема, таким вимогам, як відсутність непогашеної або не знятої в установленому законодавством порядку судимості за вчинення умисного злочину, а також відсутність вироку суду, за яким працівника засуджено до позбавлення права обіймати певні посади та займатися певною діяльністю. Зроблено висновок, що керівник та головний бухгалтер для того, щоб бути призначеним на свою посаду, протягом останніх п'яти років, що передують призначенню, не повинен бути керівником, фінансовим директором або головним бухгалтером фінансової установи, визнаної банкрутом, підданої процедурі примусової ліквідації або до якої було застосовано захід впливу відповідним органом, який здійснює регулювання ринків фінансових послуг, у вигляді відсторонення керівництва від управління фінансовою установою та призначення тимчасової адміністрації.

Ключові слова: фінансові послуги, оплата праці, фінансова установа, службовичі, підвищення кваліфікачії.

The article emphasizes that the state creates conditions for full exercise by citizens of the right to work, guarantees equal opportunities in the choice of profession and type of activity, implements programs of vocational training, training and retraining of personnel in accordance with social needs, but at the same time, there is no complete holistic system of implementation guarantees and protection of these rights. It has been determined that the labor rights of financial institution employees should be considered in the context of two groups of rights: the fundamental rights of financial institution employees - that is, those rights that are fundamental to any spheres of hired labor, and which are, of course, certainly characteristic of institutions whose sole activity is the provision of financial services; special rights of employees of financial institutions - rights that are specific only to employees of financial institutions and which are set out in special regulatory acts that operate in this field. It has been found that certain categories of employees of financial institutions, such as the employee responsible for financial monitoring, the heads and chief accountants of financial institutions, among other things, must have a sound business reputation and meet other qualifications required by law. The business 
reputation of such employees must meet, in particular, such requirements as the absence of a criminal conviction or conviction for a premeditated crime, as well as the absence of a conviction, and the absence of a court sentence requiring an employee to be deprived of the right to occupy certain positions and occupy certain positions. It is concluded that in order to be appointed for the past five years prior to the appointment, the manager and chief accountant need not be the manager, chief financial officer or chief accountant of a financial institution declared bankrupt, subject to compulsory liquidation or before which has been subjected to a measure of influence by the relevant authority that regulates the financial services markets, in the form of removal of management from the management of a financial institution and the appointment of a temporary administrator her.

Key words: financial services, remuneration, financial institution, employees, professional development.

Вступ. Конституція України [1], заклавши основу формування якісно нового національного трудового законодавства, передбачивши у своєму змісті основні соціально-економічні права людини та проголосивши Україну соціальною державою, встановила цілу низку норм, які стосуються соціально-трудових прав громадян. Відповідно до ії положень держава створює умови для повного здійснення громадянами права на працю, гарантує рівні можливості у виборі професії та роду діяльності, реалізує програми професійного навчання, підготовки та перепідготовки кадрів відповідно до суспільних потреб. Але в той самий час Основний Закон не встановив всієї цілісної системи реалізації гарантій і захисту цих прав. Ці питання мають врегулюватись на рівні Кодексу законів про працю України [2], проте інститут трудових правовідносин одночасно охоплює широке коло сфер, а тому перманентно актуалізується необхідність у дослідженні окремих аспектів реалізації гарантій і захисту трудових прав, одним із яких $є$ реалізація трудових прав працівниками фінансових установ. Кодекс законів про працю України [2] не лише узагальнює і систематизує вже накопичений нормативний матеріал, але водночас $\epsilon$ важливим законодавчим актом, складником якого $є$ положення, які регламентують правовий статус працівника $\mathrm{i}$, зокрема, його основні права. Проте його зміст не дозволяє встановити, якими є особливості реалізації трудових прав працівниками фінансових установ, з огляду на те, що ряд їхніх аспектів урегульовано на рівні різних інших нормативно-правових актів національного законодавства.

Сьогодні основні права працівника визначаються нормами статті 2 Кодексу законів про працю України [2], і до них віднесено права на одержання роботи з оплатою праці не нижче встановленого державою мінімального розміру, включаючи право на вільний вибір професії, роду занять і роботи, на відпочинок відповідно до законів про обмеження робочого дня та робочого тижня і про щорічні оплачувані відпустки, право на здорові і безпечні умови праці, на об'єднання в професійні спілки та на вирішення колективних трудових конфліктів (спорів) у встановленому законом порядку, на участь в управлінні підприємством, установою, організацією, на матеріальне забезпечення в порядку соціального страхування в старості, а також у разі хвороби, повної або часткової втрати працездатності, на матеріальну допомогу в разі безробіття, на право звернення до суду для вирішення трудових спорів незалежно від характеру виконуваної роботи або займаної посади, крім випадків, передбачених законодавством, та інші права. В той самий час розвиток ринкової економіки і демократизація трудових відносин актуалізували потребу по-новому розглянути правовий статус працівника і основні права працівника як його елемент, зокрема, правовий статус працівника, працевлаштованого у певній сфері національної економіки, наприклад, сфері функціонування фінансових установ. Така переоцінка $є$ важливою для формування розуміння важливості створення умов для ефективного залучення якісного персоналу у цю сферу, підвищення продуктивності, об'єднання в таких трудових відносинах інтересів працівника і роботодавця як основних соціальних партнерів, адже проголошення на рівні Основного Закону держави права людини на вільний розвиток своєї особи, включаючи право розпоряджатися своєю здатністю до праці, істотно змінило зміст основних прав працівника як суб'єкта трудового права, одночасно актуалізувавши науковий інтерес до таких питань, як особливості реалізації трудових прав працівниками фінансових установ.

Стан дослідження. Питанням визначення правової природи трудових прав працівника в окремих аспектах приділяли увагу такі вчені, як 3.В. Білоус, В.С. Венедіктов, С.В. Вишновецька, К.М. Гусов, В.В. Жернаков, С.О. Іванов’ М.І. Іншин, І.Я. Кисельов, Л.В. Котова, В.В. Лазор, Л.I. Лазор, І.О. Ієрусалімова, Н.В. Лазукова, С.М. Прилипко, В.І. Прокопенко, О.І. Процевський, Л.А. Сироватська, Н.М. Хуторян, Г.І. Чанишева, І.І. Шамшина, О.М. Ярошенко. Але при цьому 
варто враховувати, що ряд теоретичних і практичних питань у сфері регулювання трудових прав працівника ще залишаються невирішеними, і одним із них $\epsilon$ питання особливостей реалізації трудових прав працівниками фінансових установ. В умовах, коли питання, пов'язані із трудовими правами працівників фінансових установ, $є$ невстановленими на науковому рівні, науково-теоретичне дослідження особливостей їх реалізації є актуальною темою.

Постановка завдання. Метою статті є дослідження особливостей реалізації трудових прав працівниками фінансових установ.

Результати дослідження. Трудові права працівників відображають основні права і свободи особистості' закріплені в таких міжнародних актах' як Загальна декларація прав людини від 10.12.1948 року [3], Міжнародних пактах про громадянські і політичні права від 16.12.1966 року [4]' про економічні' соціальні і культурні права від 16.12.1966 року [5], Декларація МОП основних принципів та прав у світі праці від 18.06.1998 року [6] та ряд інших нормативно-правових актів. У вітчизняному законодавстві основні права працівника як суб'єкта трудового права закріплені в Конституції України [1] і в Кодексі законів про працю [2].

Основу для трудових прав працівників фінансових установ в Україні становлять положення Конституції України [1], у статті 43 якої визначено ті права, які є фундаментальними для будь-якої сфери трудової діяльності, а отже, й сфери трудових відносин у діяльності банків, кредитних спілок, ломбардів, лізингових компаній, довірчих товариств, страхових компаній, установ накопичувального пенсійного забезпечення, інвестиційних фондів і компаній та інших юридичних осіб, винятковим видом діяльності яких є надання фінансових послуг, а у випадках, прямо визначених законом, - інших послуг (операцій), пов'язаних з наданням фінансових послуг. Зокрема, такими правами є: кожен має право на працю, що включає можливість заробляти собі на життя працею, яку він вільно обирає або на яку вільно погоджується; держава створює умови для повного здійснення громадянами права на працю, гарантує рівні можливості у вибоpi професії та роду трудової діяльності, реалізовує програми професійно-технічного навчання, підготовки і перепідготовки кадрів відповідно до суспільних потреб; використання примусової праці забороняється; громадянам гарантується захист від незаконного звільнення; право на своєчасне одержання винагороди за працю захищається законом. Це означає, що кожна особа, яка бажає заробляти собі на життя працею у фінансових установах, має право на вибір такого виду праці або ж погоджуватись на працю у цій сфері. Держава гарантує рівні можливості у виборі професії та роду трудової діяльності, тому кожен, хто бажає обрати професію, пов'язану із здійсненням трудової діяльності в фінансових установах, не може зазнавати жодних дискримінацій, пов'язаних із цим. У кожного є можливості здобути необхідну для цієї сфери освіту чи підготовку, удосконалювати свої навички та вміння у процесі здійснення трудової діяльності в установах, винятковим видом діяльності яких $є$ надання фінансових послуг або пов'язаних із фінансовими послуг. Окрім того, нікого не може бути примушено до праці у фінансових установах, а тим, хто працює у фінансовій сфері, надано ряд гарантій (захист від незаконного звільнення, на своєчасну виплату заробітної плати, на безпечні, належні та здорові умови праці, на оплату праці, не нижчу від встановленої законом, та інші гарантії).

Отже, права, встановлені Конституцією України [1], мають загальний характер і поширюються на працівників усіх сфер національної економіки. Жодне із перерахованих прав не визначає особливості реалізації трудових прав працівниками фінансових установ порівняно із працівниками, задіяними у інших сферах. Але при цьому варто враховувати, що передбачені Основним Законом права $є$ тим фундаментом, який $є$ визначальним для праці у цій сфері, і перераховані нами права $\epsilon$ невіддільними. Всіма іншими трудовими правами працівники фінансових установ наділяються на основі та із урахуванням цього фундаменту для їх правового статусу.

Іншим нормативно-правовим актом, що встановлює загальні трудові права працівників фінансових установ, $є$ Кодекс законів про працю України [2], який визначає умови праці, особливості регулювання трудових відносин, головні права та гарантії для працівників фінансових установ, а також обов'язок працівників виконувати передбачені трудові обов'язки. Зокрема, у статті 2 цього нормативно-правового акту до основних трудових прав віднесено право громадян України на працю, тобто на одержання роботи з оплатою праці не нижче встановленого державою мінімального розміру, включаючи право на вільний вибір професії, роду занять і роботи, що забезпечується державою. Л.В. Котова доходить висновку, що більшість із цих прав $є$ основними і входять до змісту правового статусу будь-якого працівника як суб'єкта трудового права, належать працівнику як особистості і здійснюються індивідуально [7, с. 509]. Отже, право громадян Україн на працю безумовно поширюється і на осіб, які його реалізовують, вступаючи у трудові пра- 
вовідносини із банками, кредитними спілками, ломбардами, лізинговими компаніями, довірчими товариствами, страховими компаніями, установами накопичувального пенсійного забезпечення, інвестиційними фондами і компаніями та іншими юридичними особами, винятковим видом діяльності яких є надання фінансових послуг чи інших послуг, пов'язаних з наданням фінансових послуг. Це право свідчить про те, що кожна особа має право на працевлаштування у фінансовій установі у тому разі, коли вона відповідає тим вимогам, які ставляться до працівників таких установ. У разі працевлаштування заробітна плата такої особи не може бути меншою за встановлений та гарантований державою законодавчий мінімум.

Також у статті 2 Кодексу законів про працю України [2] визначено, що держава створює умови для ефективної зайнятості населення, сприяє працевлаштуванню, підготовці і підвищенню трудової кваліфікації, а за необхідності забезпечує перепідготовку осіб, вивільнюваних у результаті переходу на ринкову економіку. Це право поширюється і на осіб, працевлаштованих у фінансових установах, для яких створено особливі умови для підготовки та підвищення кваліфікації. Наприклад, вітчизняним законодавцем було прийнято Положення про навчання, перепідготовку, підвищення кваліфікації та складання екзаменів особами, які провадять діяльність на ринках фінансових послуг [8]. А тому зробимо висновок, що це право реалізовується працівниками фінансових установ у спеціальному порядку. Окрім того, у статті 2 Кодексу законів про працю України [2] регламентовано, що працівники реалізують право на працю шляхом укладення трудового договору про роботу на підприємстві, в установі, організації або з фізичною особою, а також мають права на відпочинок відповідно до законів про обмеження робочого дня та робочого тижня і про щорічні оплачувані відпустки, на здорові і безпечні умови праці, на об'єднання в професійні спілки та на вирішення колективних трудових конфліктів (спорів) у встановленому законом порядку, на участь в управлінні підприємством, установою, організацією, на матеріальне забезпечення в порядку соціального страхування в старості, а також у разі хвороби, повної або часткової втрати працездатності, на матеріальну допомогу в разі безробіття, на право звернення до суду для вирішення трудових спорів незалежно від характеру виконуваної роботи або займаної посади, крім випадків, передбачених законодавством, та інші права, встановлені законодавством. Зазначений перелік основних трудових прав працівників безумовно поширюється і на працівників фінансових установ.

Таким чином, зробимо висновок, що трудові права працівників фінансових установ варто розглядати у розрізі двох груп прав: основних прав працівників фінансових установ, тобто тих прав, які є базовими для будь-яких сфер, у яких використовується наймана праця та які, безумовно, є характерними і для установ, винятковим видом діяльності яких є надання фінансових послуг; спеціальних прав працівників фінансових установ, тобто прав, характерних винятково для працівників фінансових установ, та які встановлені у спеціальних нормативно-правових актах, які функціонують у цій сфері.

Основні права працівників фінансових установ встановлені нами вище, і до них належать права, визначені в Конституції України [1] та Кодексі законів про працю України [2]:

1) право на працю, що включає можливість заробляти собі на життя працею у фінансовій установі, яку особа вільно обирає або на яку вільно погоджується;

2) право на рівні можливості у виборі професії та роду трудової діяльності серед тих, які дають можливість працевлаштуватись у фінансових установах, на підготовку і підвищення трудової кваліфікації, а за необхідності перепідготовку, для того, щоб відповідати високим вимогам та стандартам, які ставляться до працівників фінансових установ;

3) право на своєчасне одержання винагороди за працю та в розмірі, не меншому за законодавчо передбачений мінімум, та на своєчасну їі виплату з урахуванням кількості і якості виконаної роботи;

4) право на вільне укладання, зміну і розірвання трудового договору із фінансовою установою, відповідно до положень чинного законодавства про працю та спеціальних нормативно-правових актів, які врегульовують діяльність фінансових установ;

5) право на відсутність дискримінацій під час трудового процесу в фінансових установах, тобто на рівні можливостей, i рівне ставлення під час вирішення будь-яких питань у трудових i тісно пов'язаних з ними відносинах;

6) право на належні, здорові і безпечні умови праці, які мають бути забезпечені фінансовими установами;

7) право на матеріальну підтримку працівника фінансової установи у разі настання страхового випадку, передбаченого положеннями загальнообов'язкового страхування працівника, в старості, а також у разі хвороби, повної або часткової втрати працездатності; 
8) право на відпочинок, включаючи обмеження робочого дня та тижня, відповідно до положень законодавства про працю, вихідні і святкові дні, щорічну оплачувану відпустку;

9) право на участь в управлінні фінансовою установою, у тому числі на об'єднання в професійні спілки та на вирішення колективних трудових конфліктів (спорів) у встановленому законом порядку.

Проте у той самий час варто враховувати, що ряд спеціальних нормативно-правових актів встановлює спеціальні права працівників фінансових установ, характерні винятково для них та які встановлені у спеціальних нормативно-правових актах, які функціонують у цій сфері.

Зокрема, таким нормативно-правовим актом є Закон України «Про банки та банківську діяльність» від 07.12.2000 № 2121-III [9], зміст статті 42 якого дозволяє зробити висновок про те, що реалізація трудових прав керівниками, головними бухгалтерами банків має здійснюватись із урахуванням інтересів банку та дотриманням вимог чинного законодавства, положень статуту та інших документів банку. Зокрема, керівники банку повинні відповідати кваліфікаційним вимогам щодо ділової репутації та професійної придатності, мати бездоганну ділову репутацію. Професійна придатність керівника банку визначається як сукупність знань, професійного та управлінського досвіду особи, необхідних для належного виконання посадових обов'язків керівника банку з урахуванням бізнес-плану та стратегії банку, а також функціонального навантаження та сфери відповідальності конкретного керівника банку. Головний бухгалтер банку та його заступники повинні мати вищу освіту у сфері бухгалтерського обліку та аудиту і досвід роботи за фахом у банківському та/або фінансовому секторі у сукупності не менше п'яти років - для головного бухгалтера, двох років - для заступників головного бухгалтера. Керівники банку протягом усього часу обіймання відповідних посад повинні відповідати кваліфікаційним вимогам, а незалежні директори - також вимогам щодо їх незалежності. Банк повинен самостійно перевіряти відповідність керівників банку кваліфікаційним вимогам, а щодо незалежних директорів - також вимогам щодо їх незалежності, та забезпечувати контроль такої відповідності на постійній основі. Голові, членам правління банку та головному бухгалтеру банку заборонено займати посади в інших юридичних особах (крім материнських та дочірніх компаній, банківських спілок та асоціацій). Керівники банку зобов'язані діяти в інтересах банку, дотримуватися вимог законодавства, положень статуту та інших документів банку, несуть відповідальність перед банком за збитки, завдані банку їхніми діями (бездіяльністю).

Відповідно до Закону України «Про Національний банк України» від 20.05.1999 № 679-XIV [10] члени Ради Національного банку отримують винагороду, розмір якої визначається відповідно до методики, затвердженої Радою Національного банку. Відповідно до Регламенту Ради Національного банку України членам Ради Національного банку оплачуються витрати, здійснені у зв'язку з реалізацію функціональних повноважень. Правління НБУ визначає організаційно-правову структуру та основи Національного банку та затверджує положення про структурні підрозділи та установи Національного банку, статути його підприємств, порядок призначення керівників підрозділів тощо. Крім того, положення про підрозділ внутрішнього аудиту та порядку призначення керівника підрозділу внутрішнього аудиту. Голова Національного банку як посадова особа фінансової установи видає акти організаційного та розпорядчого характеру, які є обов'язковими до виконання службовцями Національного банку. Щодо службовців Національного банку, то вони є державними службовцями, і на них поширюються вимоги законодавства про державну службу та Кодексу етики працівників Національного банку [11]. Тобто до нормативно-правового забезпечення службовців Національного банку входить законодавство у сфері державної служби, а також Правила внутрішнього трудового розпорядку та посадові інструкції. На інших працівників, які не підпадають під дію цих норм, поширюються інші вимоги трудового законодавства. Правила внутрішнього трудового розпорядку [12] для працівників Національного банку України визначають загальні положення, порядок прийняття та звільнення службовців та іншого персоналу, головні права та обов'язки службовців та іншого персоналу, робочий час та час відпочинку, заохочення за успіхи в роботі, відповідальність за порушення трудової дисципліни тощо.

Порядок навчання та складання екзамену керівниками та головними бухгалтерами встановлюється на основі Положення про навчання, перепідготовку, підвищення кваліфікації та складання екзаменів особами, які провадять діяльність на ринках фінансових послуг від 25.12.2003 № 183 [8].

Особливостями реалізації трудових прав працівниками фінансових установ $є$ такі:

- службовці фінансових установ займають окреме становище у розвитку фінансової системи держави. 
Згідно зі статтею 10 Закону України «Про фінансові послуги та державне регулювання ринків фінансових послуг» від 12.07.2001 № 2664-III [13] керівник або службовець фінансової установи не можуть брати участь у підготовці та прийнятті рішення щодо прийняття фінансовою установою будь-якого зобов'язання на їх користь. Тобто основний законодавчий акт про фінансові установи визначає працівників саме як службовців, що зумовлено їх особливим та відповідальним становищем у розвитку фінансової системи держави. Всі попередньо наведені нормативні акти свідчать про окреме становище працівників фінансових установ серед інших категорій найманих працівників.

- працівники фінансових установ мають володіти високим професійним рівнем.

Законодавець приділяє особливу увагу питанню професійного рівня працівників фінансових установ, прийнявши спеціальне Положення про навчання, перепідготовку, підвищення кваліфікації та складання екзаменів особами, які провадять діяльність на ринках фінансових послуг [8], з метою забезпечення таким працівникам можливості виконання своїх обов'язків на професійному рівні, а також для поступового розширення та поглиблення знань, умінь, навичок та знання основ законодавства у сфері фінансових послуг. 3 цього випливає підвищена увага як українського законодавця, так і всього українського суспільства до питань ефективності виконання працівниками фінансових установ своїх обов'язків, що великою мірою впливає на стан розвитку та функціонування фінансової системи держави;

- до працівників ставляться специфічні вимоги, яким вони мають відповідати.

Деякі категорії службовців фінансових установ, такі як працівник, відповідальний за проведення фінансового моніторингу, керівники та головні бухгалтери фінансових установ, окрім іншого, повинні володіти бездоганною діловою репутацією та відповідати іншим кваліфікаційним вимогам, встановленим законодавством. Ділова репутація таких працівників повинна відповідати, зокрема, таким вимогам, як відсутність непогашеної або не знятої в установленому законодавством порядку судимості за вчинення умисного злочину, а також відсутність вироку суду, за яким працівника засуджено до позбавлення права обіймати певні посади та займатися певною діяльністю. Окремі вимоги до професійної підготовки ставляться до таких працівників фінансових установ, як керівники та головні бухгалтери. Так, відповідно до Професійних вимог до керівників та головних бухгалтерів фінансових установ [14] такі працівники перш ніж приступити до виконання своїх безпосередніх трудових обов'язків, повинні пройти підвищення кваліфікації та скласти екзамен на відповідність знань професійним вимогам за типовою програмою підвищення кваліфікації керівників, головних бухгалтерів, складеною за напрямом діяльності фінансової установи та затвердженою Національною комісією з регулювання ринків фінансових послуг України. Варто зауважити, що питанням професійної підготовки всіх без винятку працівників фінансових установ приділено особливу увагу з боку українського законодавця, про що свідчить прийняття Положення про навчання, перепідготовку, підвищення кваліфікації та складання екзаменів особами, які провадять діяльність на ринках фінансових послуг [8]. 3 цього можна зробити висновок, що належна професійна підготовка, бездоганна репутація та відповідність усім законодавчо закріпленим кваліфікаційним вимогам $€$ тими базовими поняттями, що складають зміст трудової правосуб' єктності працівників фінансових установ;

- працівники фінансових установ несуть додаткову відповідальність, яка слідує із їх трудових функцій.

Так, у статтях 41-44 Закону України «Про фінансові послуги та державне регулювання ринків фінансових послуг» від 12.07.2001 № 2664-III [13] встановлені негативні наслідки за притягнення до різних видів юридичної відповідальності. Специфіка юридичної відповідальності службовців фінансових установ полягає у підвищеній соціальній ролі таких працівників, які великою мірою впливають на стан функціонування та розвитку фінансової системи країни.

- наявність обмежень та заборон, які ставляться до працівників фінансових установ.

Окремо слід зупинитися на такому збірному елементі правового статусу працівників фінансових установ, як обмеження та заборони. 3 цього приводу слід сказати про їх достатню кількість в законодавчих актах, що стосуються регулювання діяльності різних видів фінансових установ. Насамперед варто звернути увагу на загальну норму, яка говорить про визначення окремих обмежень щодо надання окремих фінансових послуг законами про діяльність відповідної фінансової установи та нормативно-правовими актами державних органів, що здійснюють регулювання ринків фінансових послуг (частина 2 статті 5 Закону України «Про фінансові послуги та державне регулювання ринків фінансових послуг» від 12.07.2001 № 2664-III [13]). 
Окремо також говориться про конфлікт інтересів службовців фінансових установ та клієнтів, де головним чином закріплені певні обмеження та заборони, які фактично і формують специфіку правового статусу працівників фінансових установ. Так, у статті 10 Закону України «Про фінансові послуги та державне регулювання ринків фінансових послуг» [13] встановлено загальну заборону на участь керівника або службовця фінансової установи у підготовці та прийнятті рішення щодо прийняття фінансовою установою будь-якого зобов'язання на їх користь. Окрім цього, керівник або службовець фінансової установи не можуть брати участь у підготовці та прийнятті рішення на користь установи або підприємства, в якому вони, їх близькі родичі або підприємство, яким вони володіють, мають діловий інтерес. Свого роду обмеженням є вимога про укладання договорів між службовцем фінансової установи та фінансовою установою щодо надання такій особі відповідних фінансових послуг на умовах, що не відрізняються від звичайних.

Варто зауважити, що окремі обмеження встановлюються і для окремих груп працівників фінансових установ. Так, відповідно до Професійних вимог до керівників та головних бухгалтерів фінансових установ [14] керівник та головний бухгалтер, для того щоб бути призначеним на свою посаду, протягом останніх п'яти років, що передують призначенню, не повинен бути керівником, фінансовим директором або головним бухгалтером фінансової установи, визнаної банкрутом, підданої процедурі примусової ліквідації або до якої було застосовано захід впливу відповідним органом, який здійснює регулювання ринків фінансових послуг, у вигляді відсторонення керівництва від управління фінансовою установою та призначення тимчасової адміністрації.

Висновки. Слід зазначити, що всі наведені вище обмеження та заборони є необхідними і ніяким чином не нівелюють трудові права працівників фінансових установ, не ставлять їх у якесь нерівне становище відносно інших категорій працівників, а навпаки, свідчать про їх важливу та особливу роль у процесі здійснення фінансових операцій та ефективного обслуговування клієнтів.

\section{Список використаних джерел:}

1. Конституція України: Закон України від 28.06.1996 № 254к/96-ВР. Відомості Верховної Ради України. 1996. № 30. Ст. 141.

2. Кодекс законів про працю України: Закон України від 10.12.1971 № 322-VIII. Вiдомості Верховної Ради УРСР від 17.12.1971. Додаток до N 50.

3. Загальна декларація прав людини: Міжнародний документ від 10.12.1948. Офіційний вісник Украӥни. 2008 р. № 93. стор. 89. стаття 3103. код акта 45085/2008.

4. Міжнародний пакт про громадянські і політичні права: Міжнародний документ від 16.12.1966. URL: https: zakon.rada.gov.ua/laws/show/995_043 (дата звернення 20.01.2020 року).

5. Міжнародний пакт про економічні, соціальні і культурні права: Міжнародний документ від 16.12.1966. URL: https: zakon.rada.gov.ua/laws/show/995_042 (дата звернення 20.01.2020 року).

6. Декларація МОП основних принципів та прав у світі праці: Міжнародний документ від 18.06.1998. URL: https: zakon.rada.gov.ua/laws/show/993_260 (дата звернення 20.01.2020 року).

7. Котова Л.В. Основні трудові права працівника: правова природа та перспективи розвитку. Форум права. 2011. No 1. С. 507-515.

8. Про затвердження Положення про навчання, перепідготовку, підвищення кваліфікації та складання екзаменів особами, які провадять діяльність на ринках фінансових послуг: Розпорядження Державної комісії з регулювання ринків фінансових послуг України від 25.12.2003 № 183. Офіиійний вісник України. 2004 р. № 5. Стор. 93.

9. Про банки і банківську діяльність: Закон України від 07.12.2000 № 2121-III. Відомості Верховної Ради Украӥни (ВВР). 2001. № 5-6. Ст. 30.

10. Про Національний банк України: Закон України від 20.05.1999 № 679-XIV. Вiдомості Верховної Ради України (ВВР). 1999. № 29. Ст. 238.

11. Кодекс професійної поведінки та етики працівників AT «Піреус Банк MКБ» URL: http: piraeusbank.ua/i_upload/code $\% 20 \mathrm{of} \% 20$ conduct $\% 20 \mathrm{ukr} \% 281 \% 29$.pdf.

12. Правила внутрішнього трудового розпорядку для працівників Національного банку України. URL: http: bank.gov.ua/control/uk/publish/article?art_id=86889.

13. Про фінансові послуги та державне регулювання ринків фінансових послуг: Закон України від 12.07.2001 № 2664-III. Відомості Верховної Ради Украӥни. 2002. № 1. Ст. 1

14. Про затвердження Професійних вимог до керівників та головних бухгалтерів фінансових установ: Розпорядження Державної комісії з регулювання ринків фінансових послуг України від 13.07.2004 № 1590. Офіціийний вісник Украӥни. 2004 р. № 31. Стор. 231. 